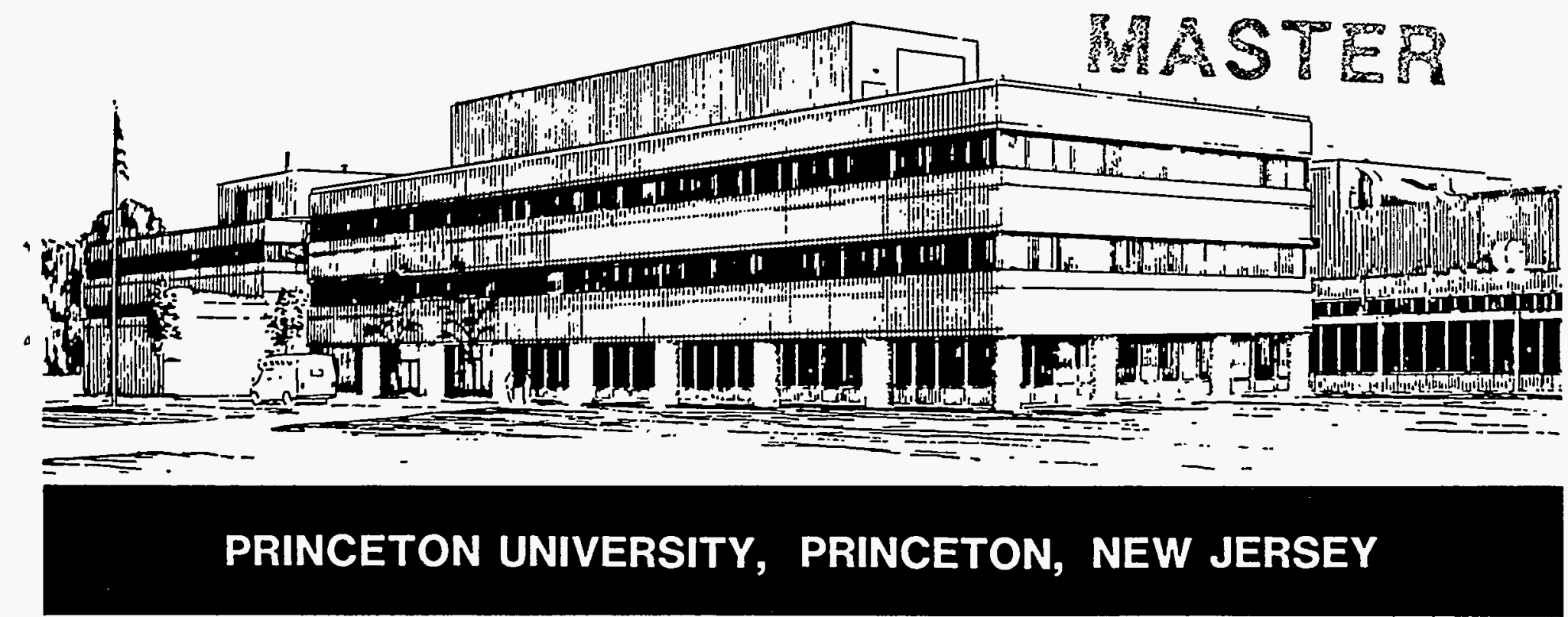




\section{NOTICE}

This report was prepared as an account of work sponsored by an agency of the United States Government. Neither the United States Government nor any agency thereof, nor any of their employees, makes any warranty, express or implied, or assumes any legal liability or responsibility for the accuracy, completeness, or usefulness of any information, apparatus, product, or process disclosed, or represents that its use would not infringe privately owned rights. Reference herein to any specific commercial produce, process; or service by trade name, trademark, manufacturer, or otherwise, does not necessarily constitute or imply its endorsement, recommendation, or favoring by the United States Government or any agency thereof. The views and opinions of authors expressed herein do not necessarily state or reflect those of the United States Government or any agency thereof.

\section{NOTICE}

This report has been reproduced from the best available copy. Available in paper copy and microfiche.

Number of pages in this report: 27

DOE and DOE contractors can obtain copies of this report from:

Office of Scientific and Technical Information

P.O. Box 62

Oak Ridge, TN 37831;

(615) 576-8401.

This report is publicly available from the:

National Technical Information Service

Department of Commerce 5285 Port Royal Road

Springfield, Virginia 22161

(703) $487-4650$ 


\section{DISCLAIMER}

Portions of this document may be illegible in electronic image products. Images are produced from the best available original document. 


\title{
Proposed Experiment to Investigate Use of Heated Optical Fibers for Tokamak Diagnostics during D-T Discharges
}

\author{
W. Tighe, P. Morgan, a) H. Adler, D. Cylinder, D. Griscom, b) D. Johnson, \\ D. Palladino, and A. Ramsey \\ Princeton University, Plasma Physics Laboratory, \\ P O Box 451, Princeton N J 08543.
}

\section{ABSTRACT}

A collaborative JET/TFTR study has been undertaken to investigate attenuation and luminescence effects due to neutron irradiation of optical fibers heated to $400^{\circ} \mathrm{C}$. It is expected that a significant improvement in fiber behavior will be observed due to thermal annealing. This technique may be important for use in fiber-related, tokamak diagnostics exposed to high neutron flux. The study will make use of aluminum jacketed, $600 \mu \mathrm{m}$ diameter, all silica ( $\mathrm{F}$-doped cladding) fibers in lengths of $150 \mathrm{~m}$. The fibers are prepared in 1 foot coils. Of the coils to be irradiated, one is heated constantly to $400^{\circ} \mathrm{C}$, a second is not heated, and a third is heated periodically. A fourth fiber coil is not to be irradiated. Spectrally and temporally resolved transmission and luminescence data under neutron irradiation during $D-T$ discharges on TFTR will be obtained. An investigation of permanent and short term effects will be made. Experimental details along with initial results will be presented.

a) JET Joint Undertaking, Abingdon, U.K.

b) Naval Research Laboratory, Washington, D.C., U.S.A.

This report is an expanded version of a paper presented at the 10th Topical Conference on High Temperature Plasma Diagnostics Rochester NY, 8-12 May 1994 and due to appear in the R.S.I. in Jan. of 1995. 


\section{Introduction .}

Fiber optics are used extensively in high temperature plasma diagnostics, primarily in the collection and transfer of visible light emission from the plasma to remote detectors. There have been extensive studies to characterize the behavior of optical fiber in nuclear, environments ${ }^{1}$. When exposed to ionizing radiation, optical fiber has been found to suffer increased absorption and induced luminescence ${ }^{2}$.

Similar effects occur when optical fiber is exposed to radiation produced during DD discharges (where the working gas is deuterium and the neutral beams inject deuterium) and trace tritium discharges on large tokamaks 3,4 . The significant increase in neutron flux during $D-T$ discharges (where the working gas is deuterium and tritium is injected with the neutral beams) is expected to enhance significantly the absorption and luminescence. Studies on TFTR (Tokamak Fusion Test Reactor) and JET (Joint European Torus) indicate that data quality and reliability may be compromised. In future devices such as TPX and ITER there is a strong need to address issues of potential damage and its avoidance, repair, or correction so fiber based diagnostics will operate satisfactorily over the lifetime of the machines 5 .

Transmission loss may be transient, showing complete recovery to pre-irradiation levels, or permanent when, under neutron bombardment, vacancies in the glass structure are created. The physical mechanisms for transmission loss have been studied 6 and involve a complex array of short-lived color centers and permanent damage sites. Thermal annealing has been found to remove some of the incurred damage. The temperature required to remove the dominant loss mechanisms and allow this partial recovery of the transmission, is typically larger than $400^{\circ} \mathrm{C}$. For this study, however, our operating point of $400^{\circ} \mathrm{C}$ was determined by the 
limitations of the aluminum jacketed fibers which were used and which are described below.

\section{Motivation and Objectives}

A JET/TFTR collaboration was undertaken to determine the effect of neutron irradiation on optical fiber operating at high temperature. The primary objective was to compare the transient and permanent transmission loss between a heated and an unheated fiber. Both spectrally and temporally resolved data are required. The initial wavelength region to be considered was the visible region from 400 $700 \mathrm{~nm}$, relevant to many diagnostics. Time scales on the order of $10-100 \mathrm{~ms}$ are needed to resolve changes during the irradiation pulse (1-2 seconds of D-T neutrons) and long time scales (10 - 1000 seconds) to examine the recovery phase.

An additional objective was to investigate the effects of temperature on fiber luminescence. Two sources of luminescence may exist. Neutron induced damage centers may emit recombination radiation resulting in so-called radioluminescence. ${ }^{7}$ Alternatively, emission from the tokamak may lead to high energy electrons propagating through the fiber faster than the speed of light, resulting in Cerenkov radiation. 8 Cerenkov radiation should display a distinct spectral signature $\left(1 / \lambda^{2}\right)$, follow the radiation time history, and be insensitive to operating temperature. Radioluminescence should be reduced and possibly eliminated in the heated fiber.

Further objectives include investigations of the behavior of a periodically annealed fiber, photobleaching and numerical aperture effects. Photobleaching has been observed when intense light sources have been propagated through the fiber. This effect is most clear in experiments using light levels which exceed that used in this study by 2 or 3 orders of magnitude. Measurements of numerical aperutre taken 
before and after irradiation should indicate if there is preferential transmission loss for specific propagation modes within the fiber.

The fiber selected for the study was an all silica, aluminum coated fiber with higher sensitivity to neutron damage (Oxford Electronics, HPSIR series, low $\mathrm{OH}$ content - $5 \mathrm{ppm}, 600 \mu \mathrm{m}$ core diameter). This fiber has good red and infra-red spectral response but absorbs very strongly below $450 \mathrm{~nm}$. To enhance the effects of nuclear irradiation, $150 \mathrm{~m}$ lengths of fiber were used and coiled into loops $~ 1$ foot in diameter.

\section{Experimental Setup.}

The set up is shown in fig. 1. Three fiber loops were wrapped in heating tape and then with an insulating tape. They were placed in individual ovens and stacked just below the outside structure of the tokamak (see figs. $2 \& 3$ ). Two of the fibers were taken from the same preform and were selected for the comparative studies. Throughout this paper they will be referred to as the heated and unheated fiber. The third fiber from a different preform was not heated and was selected for periodic annealing.

The current to the heating tape is controlled remotely. Thermocouples are used to monitor the oven temperature. Each oven was constructed from 2,2 inch slabs of calcium silicate that were channeled out to accept the wrapped fiber loop. Approximately 2 hours are needed to reach $400^{\circ} \mathrm{C}$ and $\sim 6$ hours to return to room temperature. The temperature variation within the oven is $\sim 10^{\circ} \mathrm{C}$.

The light source is located in the Hot Cell, next to the Test Cell. A schematic of the source is provided in fig. 4 . The lamp filament was reimaged with a condenser lens and then transmitted through a rotating chopper wheel using a linear array of 
microlenses. The chopper wheel is geared to rotate at either $1800 \mathrm{rpm}$ or $900 \mathrm{rpm}$. The wheel (Optical Coating Laboratory, model VC180-017) consists of two halves: a continuously filtered region and an opaque region. The filter scans the visible region from $400-700 \mathrm{~nm}$. The light transmitted through the filter is launched using microlenses into $800 \mu \mathrm{m}$, PCS lead-in fibers. These fibers carried the source light through a penetration in the Test Cell wall and across to the coils in the Test Cell (a distance of $\sim 20 \mathrm{~m}$ ). Fibers are terminated with Amphenol ST-connectors throughout.

Returning from the Test Cell coils, $800 \mu \mathrm{m}$ PCS fibers are again used. In the Hot Cell these lead-out fibers are connected to a patch panel. The output can then be directed either to an array of photomultiplier tubes (PMTs) or a $1 / 4 \mathrm{~m}$ spectrometer. The arrangement of the detectors is shown in figure 5 . To account for effects in the lead-in/lead-out fibers, two sets of these fibers are connected to each other in the oven location with no test coil contained in the loop.

A single short $(1 \mathrm{~m}) 800 \mu \mathrm{m}$ fiber connects the source to a PMT to provide constant monitoring of the source. The output of the PMTs is amplified and then digitized and stored using the TFTR data acquisition system (CICADA). Since the source wavelength is varying with the filter wheel rotation, the PMT signal can be binned into spectral components. At $1800 \mathrm{rpm}$, the spectral region and a blank region is sampled every $60 \mathrm{~ms}$. The blank region allows a period in which the PMTs can be used to measure, spectrally unresolved luminescence.

The spectrometer (SPEX, 270M spectrograph) is arranged with four fiber inputs. The $\mathrm{f} / \#$ of the inputs are optically matched to the spectrometer. A CCD camera (Wright Instruments, peltier cooled, $1152 \times 770$ pixels) is used as the detector. A $300 \mathrm{l} / \mathrm{mm}$ grating provided a $200 \mathrm{~nm}$ range on the camera. The input slit and the 
central wavelength can be quickly and easily adjusted using a hand-held controller. Two exposures taken on separate discharges are needed to cover the range from $400-700 \mathrm{~nm}$. A trigger signal generated from the filter wheel allows the read-out of the $\mathrm{CCD}$ to be synchronized with light and dark periods of the source. Reliable read-out of the camera requires the filter wheel be slowed to 900 rpm which provides spectrally resolved transmission and luminescence data every $133 \mathrm{~ms}$. Data is taken for periods up to 6 seconds. A personal computer is used for camera control and data storage.

Recently a foil activation probe has been placed in the oven location to determine actual neutron exposure. Initial results are available but the analysis is not yet complete.

\section{Initial Results.}

A few D-T discharges have been taken with the fibers in place. In two of these (\#75936 and \#75941) the output was directed to the spectrometer. In the rest, the output was directed to the PMT array.

Raw data from the PMT was examined. The transmission loss was evaluated in terms of $\mathrm{dB}$ using the relation; $10 \log \left(\mathrm{I}_{1} / \mathrm{I}_{2}\right)$, where $\mathrm{I}_{1}$ is the signal intensity after and $I_{2}$ is the intensity before the neutron event. On discharge \#76504 (with an estimated $4 \times 10^{9} \mathrm{D}-\mathrm{T}$ neutrons $/ \mathrm{cm}^{2}$ at the fiber loop) the unheated fiber lost $2.7 \mathrm{~dB}$ while the heated fiber lost $0.12 \mathrm{~dB}$. On the same discharge, the 800 micron PCS lead loops connected to themselves at the ovens lost 0.14 and $0.18 \mathrm{~dB}$ which accounts for most, if not all, the observed loss in the heated fiber. The third fiber, from a different preform, was unheated and lost over $4 \mathrm{~dB}$ in transmission. These results are summarised in fig. 6 . 
Initial results from the spectrometer are summarized in figs. $7-13$. The spectral response (uncalibrated) of the light source used in the transmission measurements is given in fig. 7. The rapid fall off below $500 \mathrm{~nm}$ is a result of the combination of low levels of shorter wavelength emission at the source and very strong absorption of the fiber. There is only weak indication of an absorption feature near $650 \mathrm{~nm}$.

In fig. 8 , the time history of the transmitted signal is shown for both the heated and unheated fibers. The results are virtually identical to those from the PMT detectors. The heated fiber shows $<.08 \mathrm{~dB}$ loss while the unheated fiber show $\sim 1.5$ $\mathrm{dB}$ of loss during the neutron event (from $3-4 \mathrm{~s}$ during the discharge - the time of neutral beam injection). The signal level in the unheated fiber prior to the neutron event occuring from $3-4$ seconds in the discharge is noticeably lower than that of the heated fiber. This is in part due to a loss induced in the unheated fiber from two earlier D-T discharges.

The ratio of the transmitted spectra taken after the neutron event to that taken prior to it is given in fig. 9 for both the heated and the unheated fiber. This shows a loss of $\sim 1 \%$ for the heated fiber with no noticeable spectral dependence. The unheated fiber shows a peak in the transmission loss of $>30 \%$ at $\sim 530 \mathrm{~nm}$ dropping to $\sim 10 \%$ at $700 \mathrm{~nm}$. The apparent low loss near $400 \mathrm{~nm}$ is not real and is due to the signal dropping to the background level which has not removed. Details of the spectral response of the transmission loss require further analysis.

The time history of the luminescence is given in fig. 10. Again, data for the heated and unheated fibers are shown with the neutron rate. It is clear that in both cases the luminescence closely follows the irradiation time history. Although the luminescence appears ( 20\%) brighter in the heated fiber, the level of luminescence may have been reduced. The signal level in the unheated fiber must 
be corrected for transmission loss primarily from this discharge but also from previous D-T discharges. This correction must be done carefully, treating the

luminescence as an extended source with varying transmission loss 3,9 . Spectrally the luminescence seen in the unheated and heated fibers is somewhat different. The raw spectrum for the unheated fiber is shown in fig. 11 and the ratio of the spectrum taken from the heated and unheated fibers is shown in fig. 12. As with the transmission spectra, details of the luminescence spectra requires calibration and further analysis. Nevertheless, if one accounts for the enhanced transmission loss in the green region, there appears to be a stronger short wavelength component to the luminescence from the heated fiber which may be consistent with a more Cerenkov-like spectral dependence.

\section{v. Conclusions and Future Work}

The purpose of this paper is to present an experimental approach to investigate the effect of temperature on radiation damage to optical fibers. The experimental setup was successfully configured and tested. Initial results in D-T operation have been obtained. Calibrations and error analysis are in progress. The primary conclusion drawn from the initial results is that the optical fiber heated to $400^{\circ} \mathrm{C}$ showed significantly less transmission loss than the unheated fiber. While we have selected conditions to enhance the deleterious effects of radiation on fiber performance, it would seem reasonable to conclude that potential difficulties related to normal diagnostic use of fibers in these environments would be alleviated by implementing a well-engineered design for heating the fiber.

It is necessary to continue the spectral and temporal analysis of transmission and luminescence effects. It is of interest to scan longer wavelengths with the present fiber and, moreover, to investigate a more typical diagnostic fiber with higher 
transmission in the "blue" spectral region. It is important to determine the transmission loss as a function of operating temperature since it may be possible to lower the temperature with significant cost savings. Evaluation of the long term recovery in these fibers and the potential for performance improvements by periodic annealing are further objectives of the study. 


\section{ACKNOWLEDGMENTS}

We would like to acknowledge the support of both the TFTR and JET teams. The additional assistance of J. Bartolick, B. Bergin, M. Diesso, G. Drodz, L. Guttadora M. Vocaturo and J. Wright of Wright Instruments, England, is much appreciated. The neutron foil activation probe is the work of $\mathrm{C}$. Barnes (LANL) and his colleagues at PPPL. The Al-coated fibres, the spectrometer and CCD camera are on loan from JET. This work was supported by the US. DoE Contract No. DE-AC02-76-CH0307

\section{REFERENCES:}

1 see for example:J.K. Partin, SPIE Proc. Fiber Optics in Adverse Environments II, 506, (1984) 42. or A. Robinson, SPIE Proc. Fiber Optics in Adverse Environments III. 721, (1986) 63.

2 E.J. Friebele et al., Nucl. Instrum. Methods Phys. Rev. B, 1, (1984) 335.

3 A.T. Ramsey and K.W.Hill, Rev. Sci. Instrum., 63 - 10 (1992) 4735.

4 P.D. Morgan, Proceedings of the Symposium on Fusion Technology, Sept. 1418,(1992) 169

5 A.T. Ramsey, Rev. Sci. Instrum, these proceedings.

6 D.L. Griscom, The Centennial Memorial Issue of The Ceramic Society of Japan, (1991) 923 .

$7 \quad$ M.J. Marrone, Appl. Phys. Lett. 38 (1981) 115.

8 J.E. Golob, P.B. Lyons, and L.D. Looney, IEEE Trans. Nucl. Sci, NS-24, No. 6, (1977) 2164.

9 H. Adler, et al., Rev. Sci. Instrum, these proceedings. 


\section{Figure Captions}

Fig. 1. Experimental Setup in Test Cell and Hot Cell. For clarity, not all lead fibers are shown.

Fig. 2. Schematic representation of the wrapped optical fiber.

Fig. 3. Schematic representation of the orientation of the fiber loops and ovens.

Fig. 4. Schematic of the light source used in transmission measurements showing the rotating filter wheel which continuously scans the region from $400-700 \mathrm{~nm}$ and the microlens array used to launch light down the $800 \mu \mathrm{m}$ lead-in fibers.

Fig. 5. Schematic of the detector systems. The light reurning from the Test Cell can be directed either to an array of PMT detectors or to a spectrometer outfitted with a CCD detector.

Fig. 6. Signal observed using the PMT detectors. The loss observed in the heated optical fiber is consistent with that observed in the lead-in/lead-out fibers alone. This indicates that the loss in the heated fiber loop has been completely removed.

Fig. 7. Raw spectral transmission signal taken prior to the neutron irradiation. The data drom 2 discharges has been spliced to give the wavelength region shown.

Fig. 8. Time history of transmission during a D-T discharge (\#75936). The data are integrated spectrally. The integrated neutron rate is shown for comparison.

Fig. 9. The ratio of transmission spectra taken before and after the neutron event for both the heated and unheated fibers. The data are averaged over I second windows. Transmission loss in the unheated fiber increase toward shorter wavelength. The heated fiber response is flat. Signal below $500 \mathrm{~nm}$ is weak and unreliable. 
Fig. 10. Time history of the luminescence from both a heated and unheated optical fiber during a D-T discharge (\#75941). The neutron rate is shown for comparison. The signal from the unheated fiber is not corrected for transmission loss.

Fig. 11. Raw spectral luminescence data for the unheated optical fiber taken during neutron irradiation. The data drom 2 discharges has been spliced to give the wavelength region shown.

Fig. 12. The ratio of the luminescence spectra for the unheated fiber to the heated fiber. The signal from the unheated fiber was not corrected for transmission loss. 


\section{TEST CELL}

HOT CELL
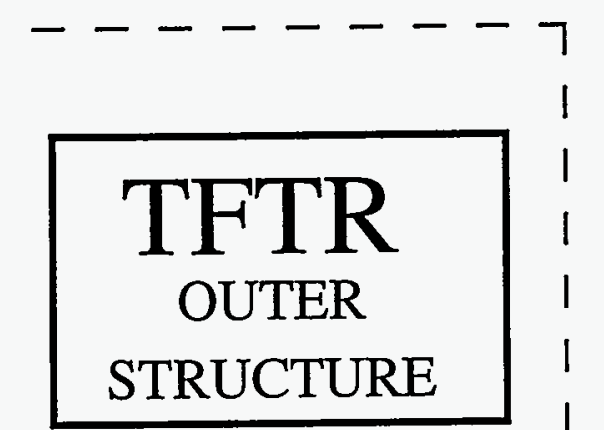

$800 \mu \mathrm{m}$ PCS

LEAD FIBERS

LIGHT SOURCE
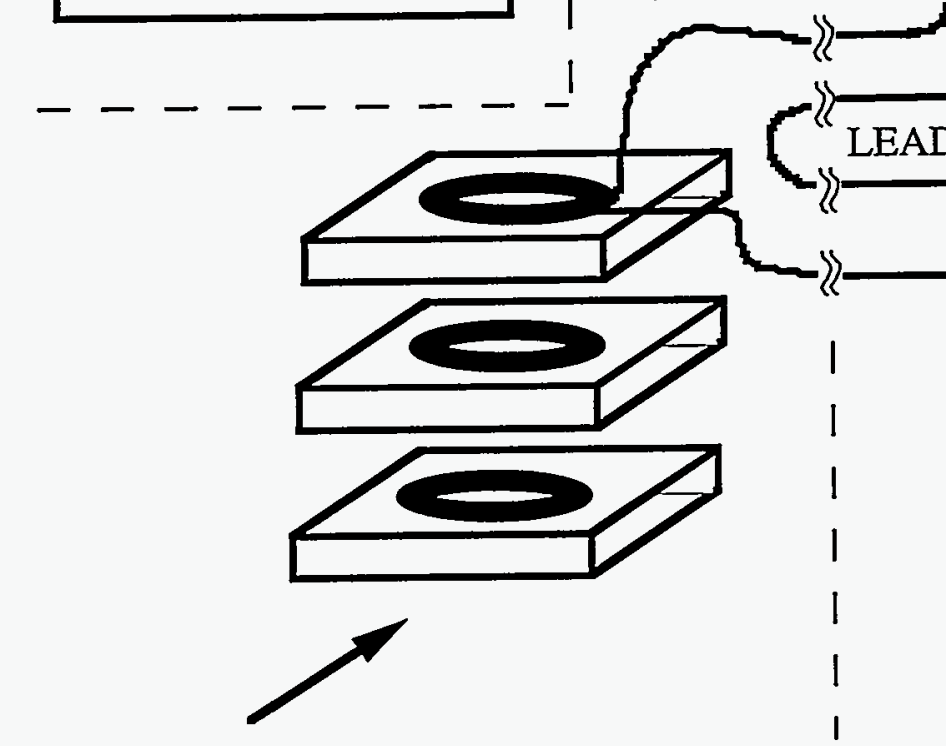

FILTER WHEEL/CHOPPER

OVENS CONTAINING $150 \mathrm{~m}$ $600 \mu \mathrm{m}$ Al Si:Si FIBER LOOPS

LEAD FIBER LOOP

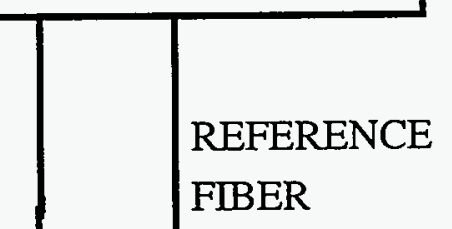

SPECTROMETER

AND

PHOTOMULTIPLIER DETECTORS

fig. 1 


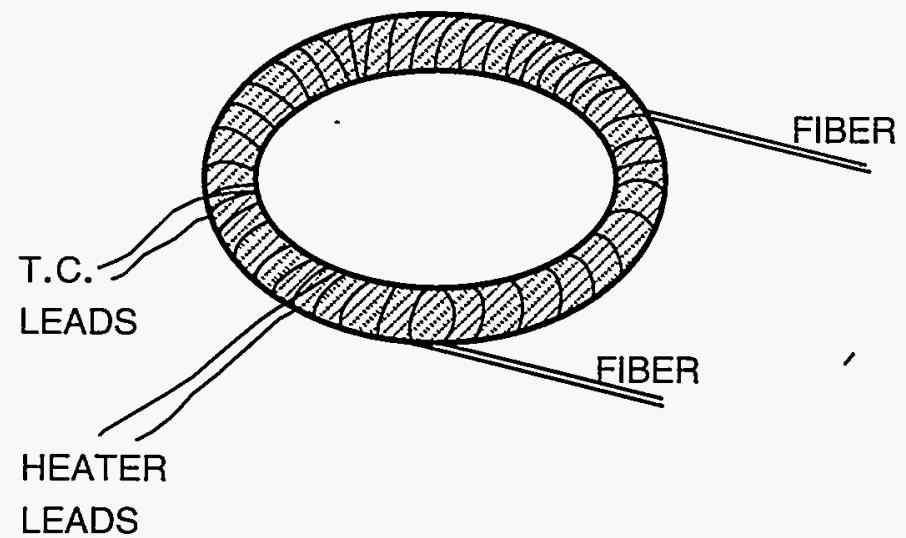

LEADS

ALUMINIUM-CLAD ALL QUARTZ FIBER 600 $M M$ DIAMETER

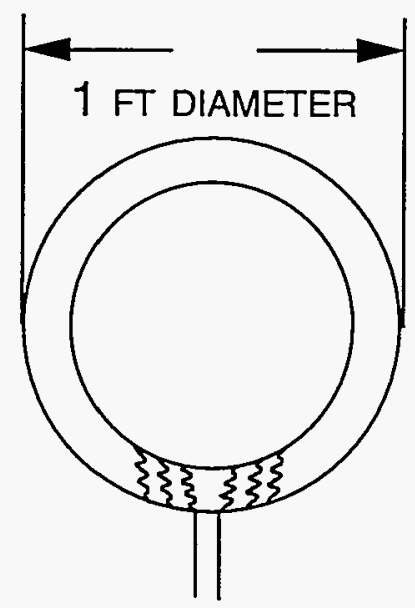

HEATER CURRENT

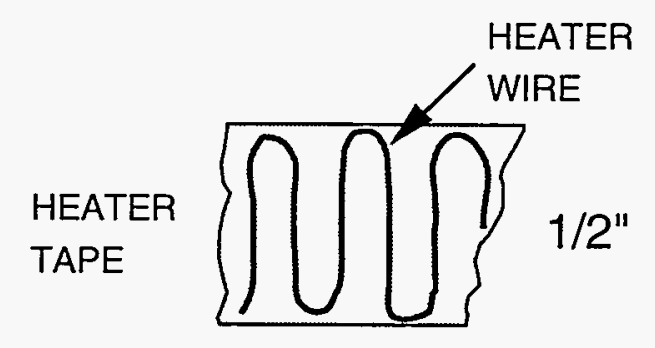

\section{fig. 2}




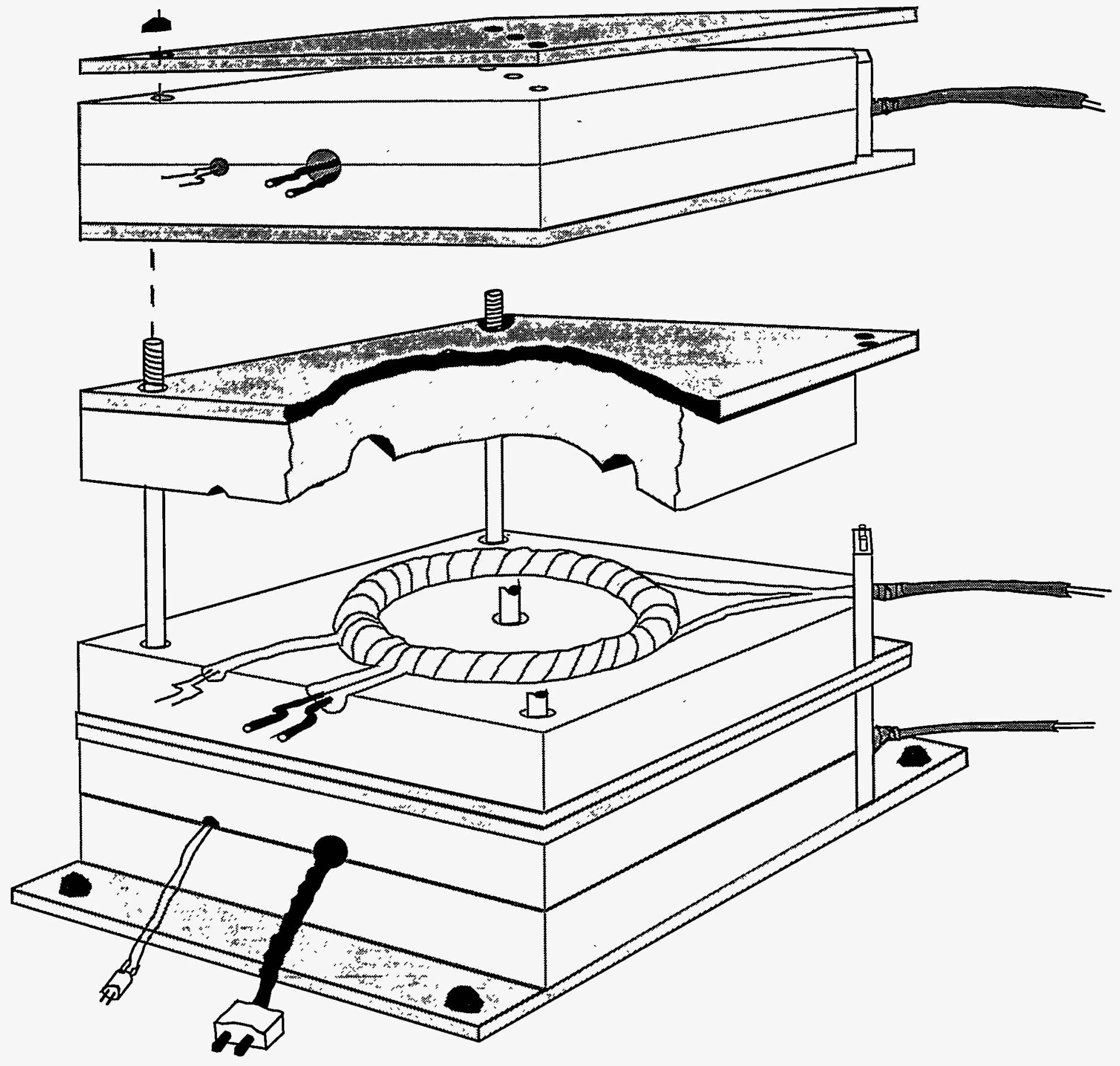

fig. 3 


\section{FILTER WHEEL RIBBON FILAMENT}
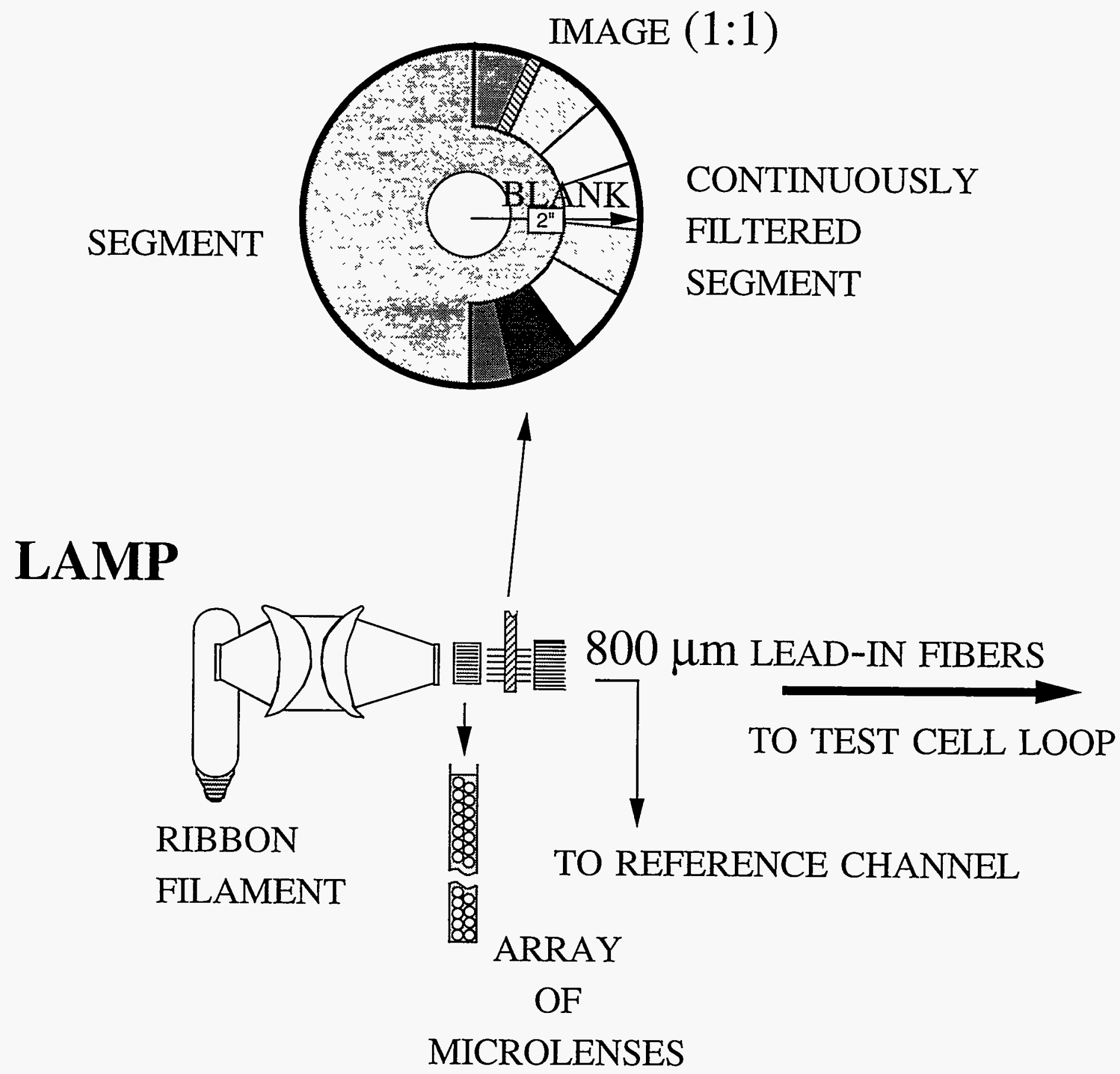

fig. 4 


\section{FIBERS FROM}

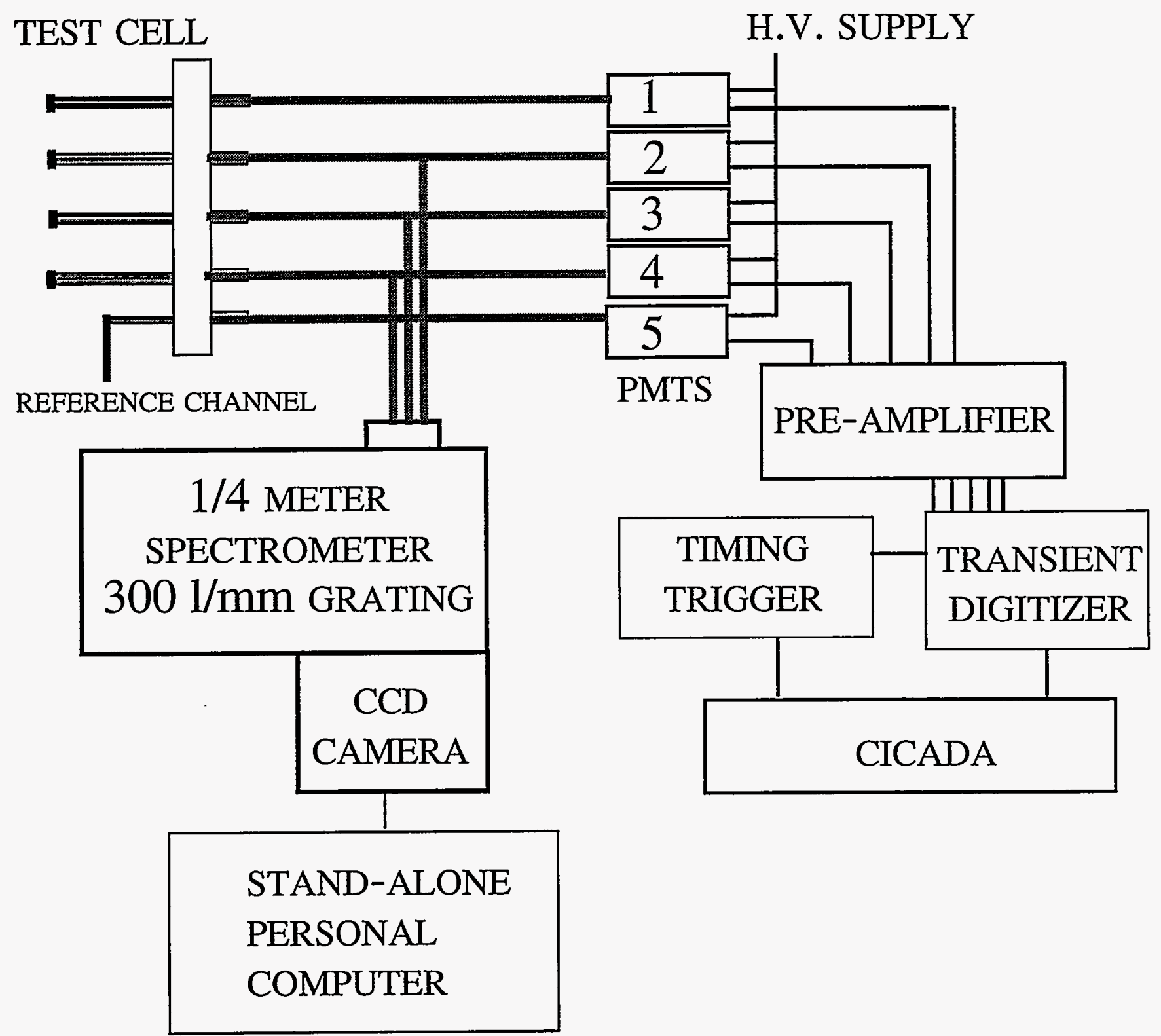

fig. 5 


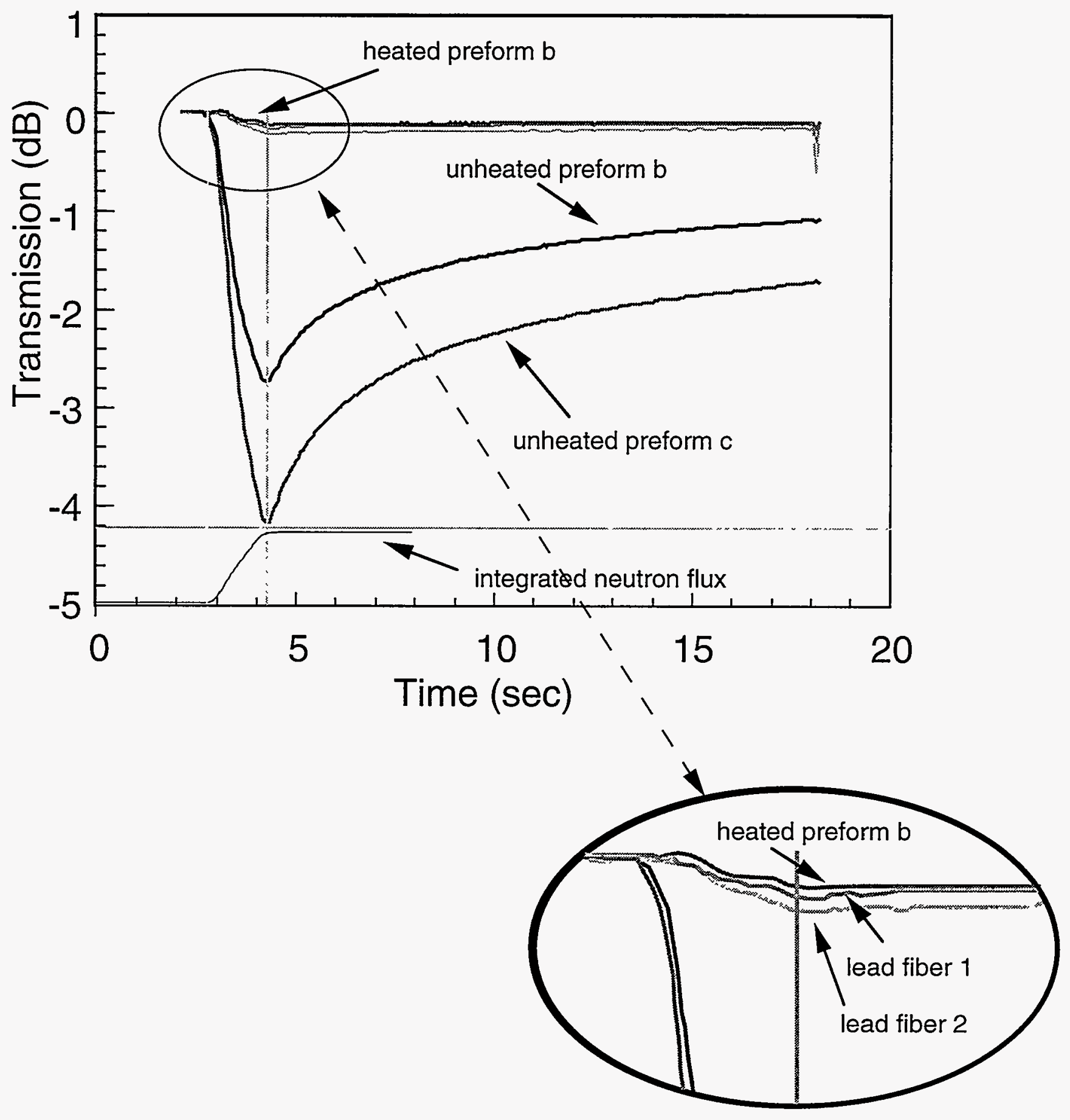

fig. 6 


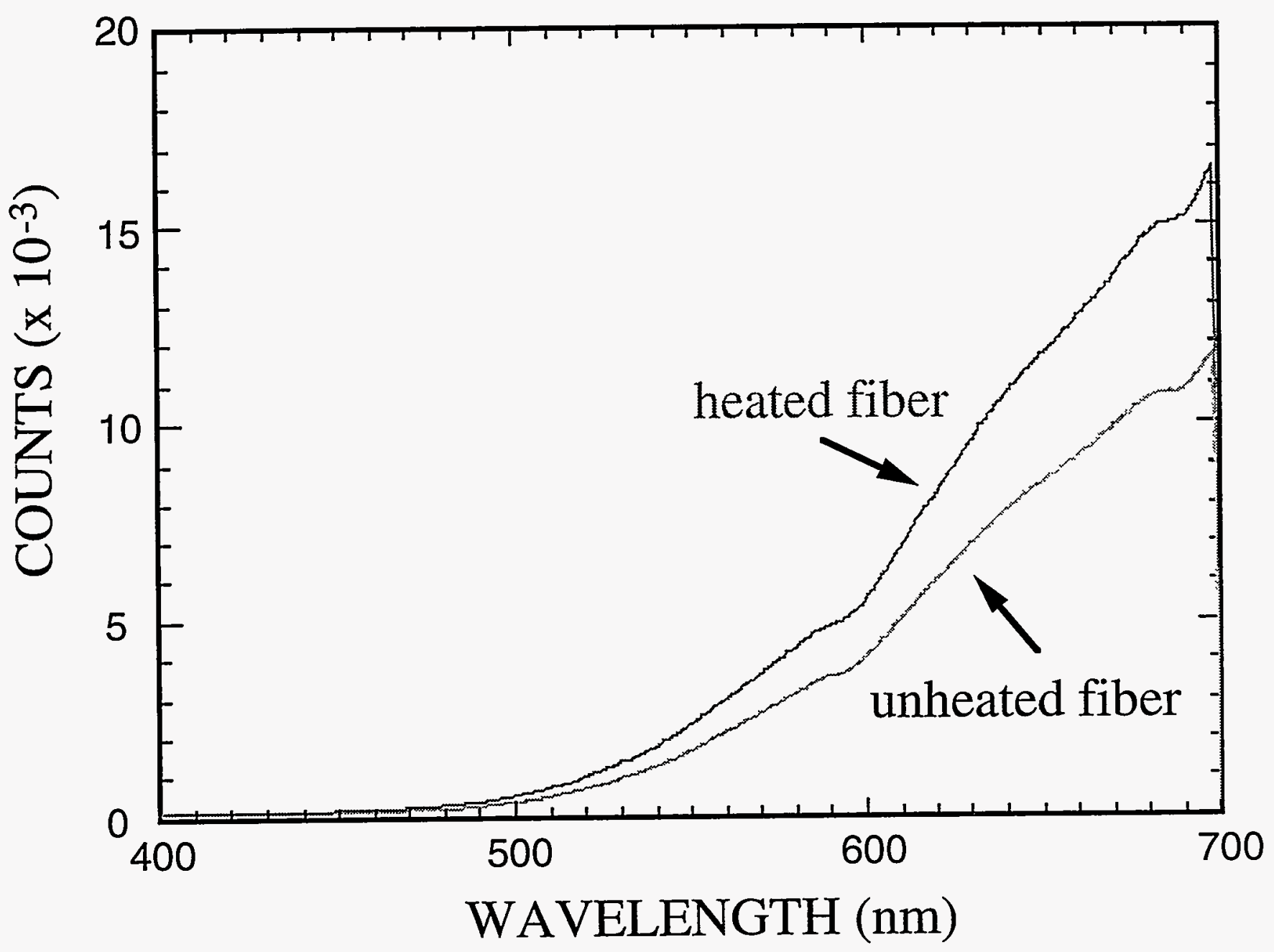

fig. 7 


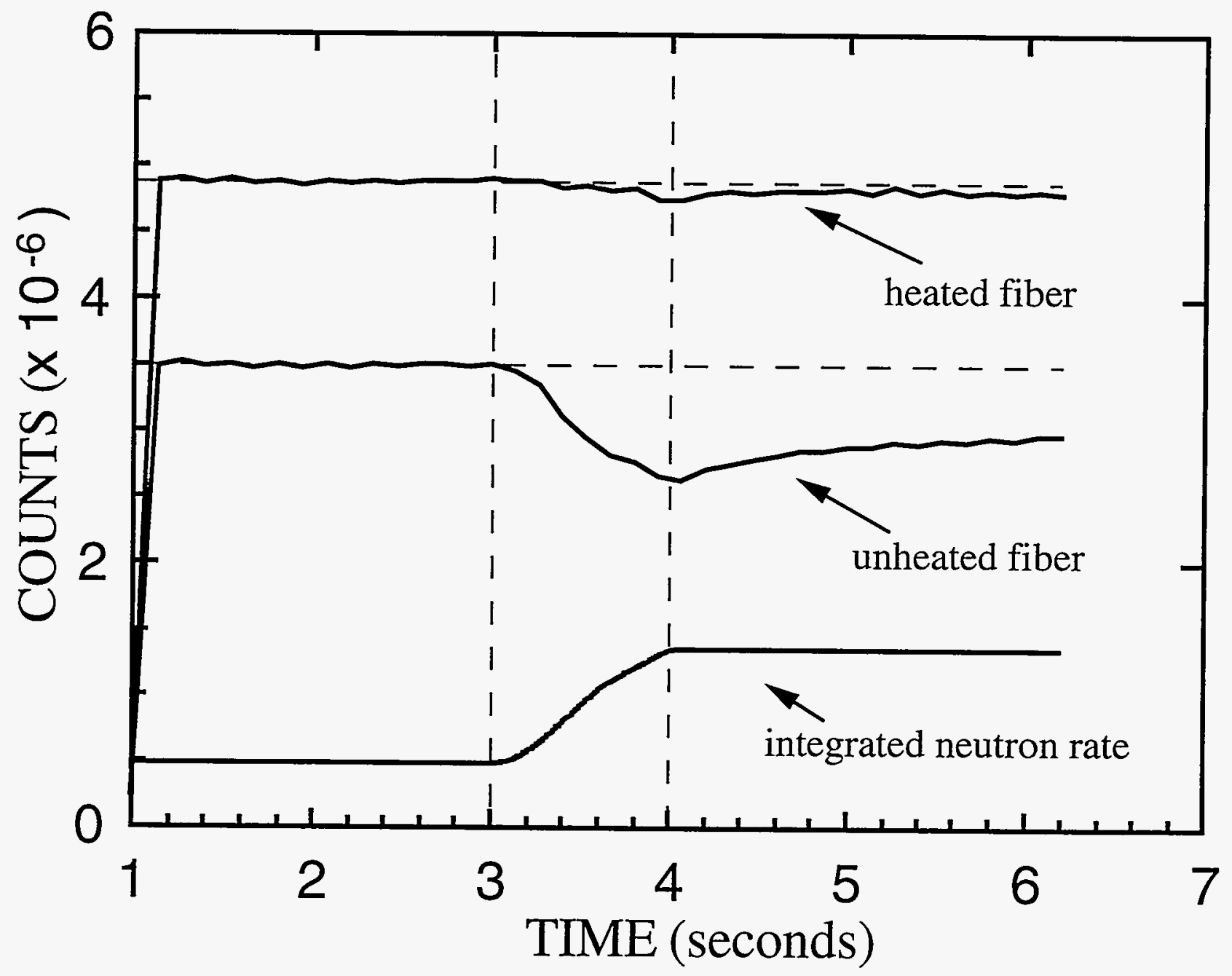

fig. 8 


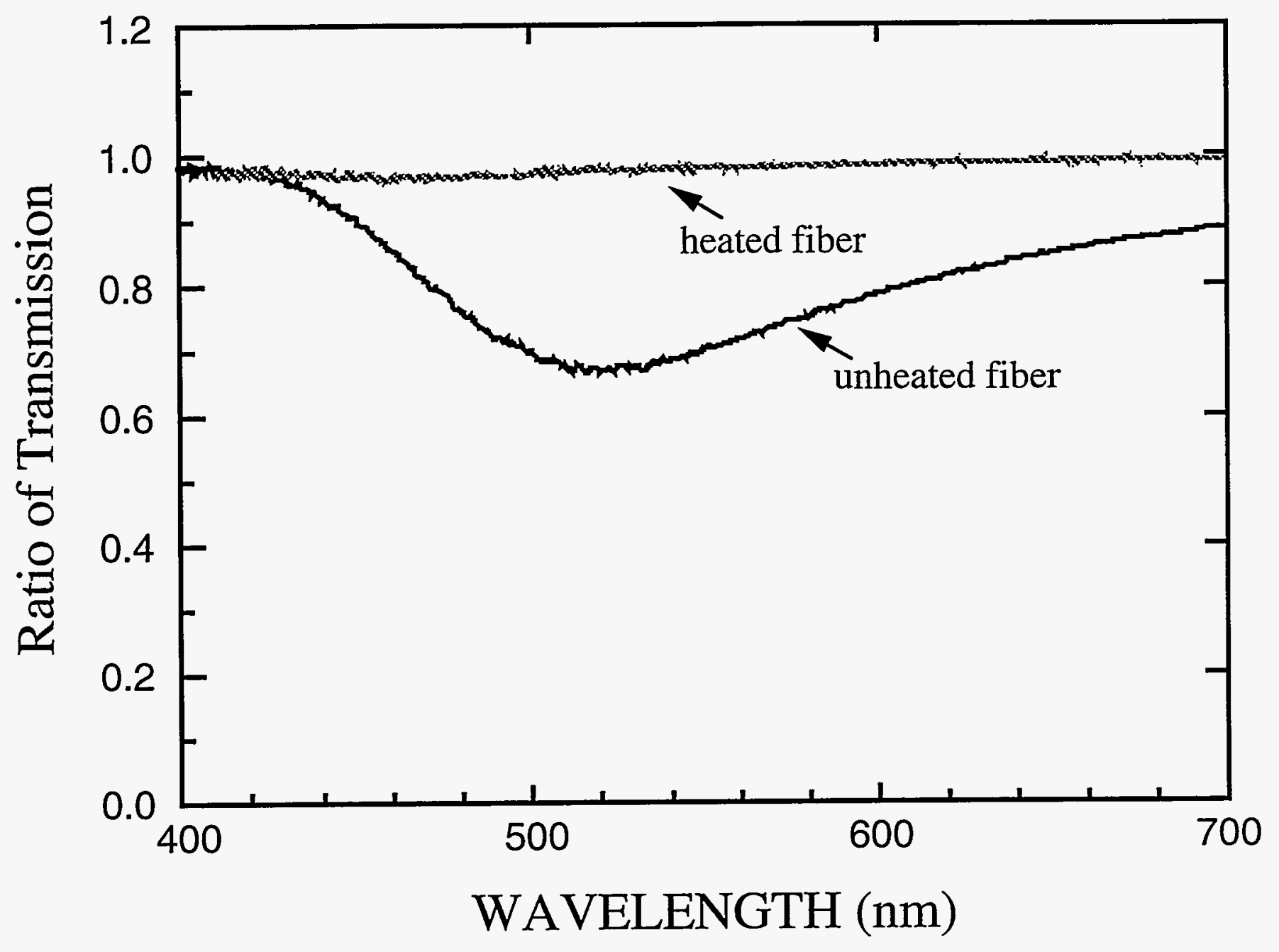

fig. 9 


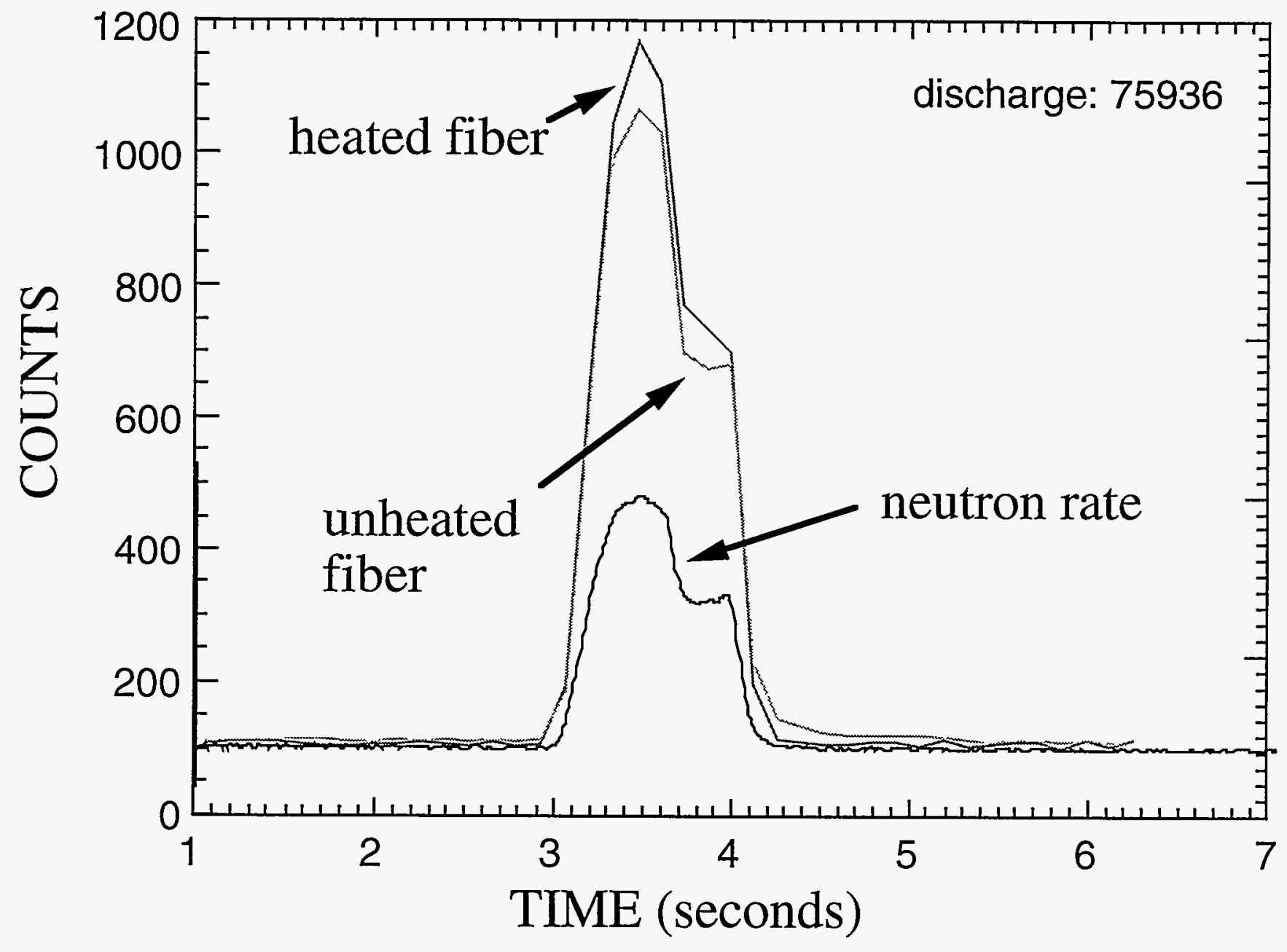

fig. 10 


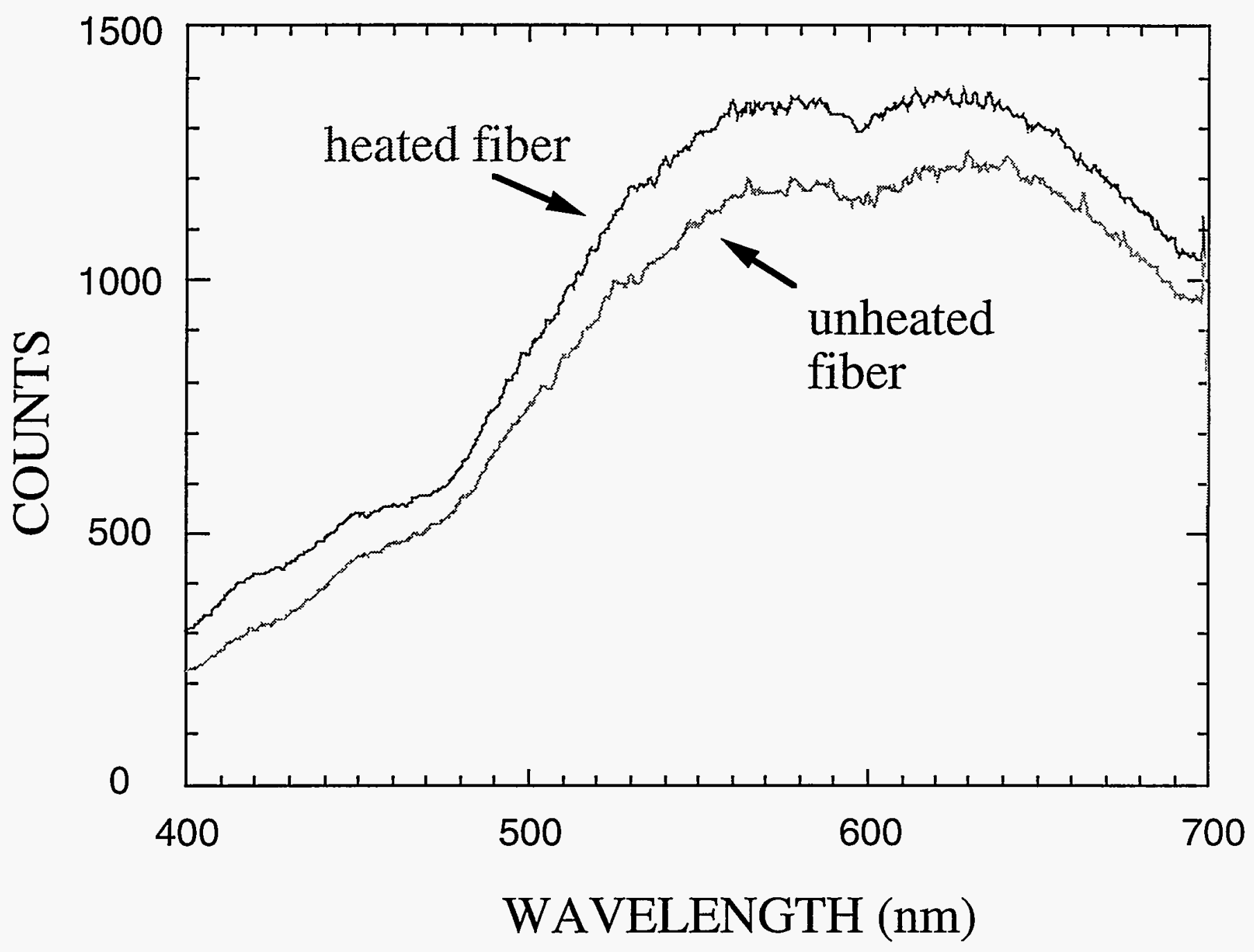

fig. 11 


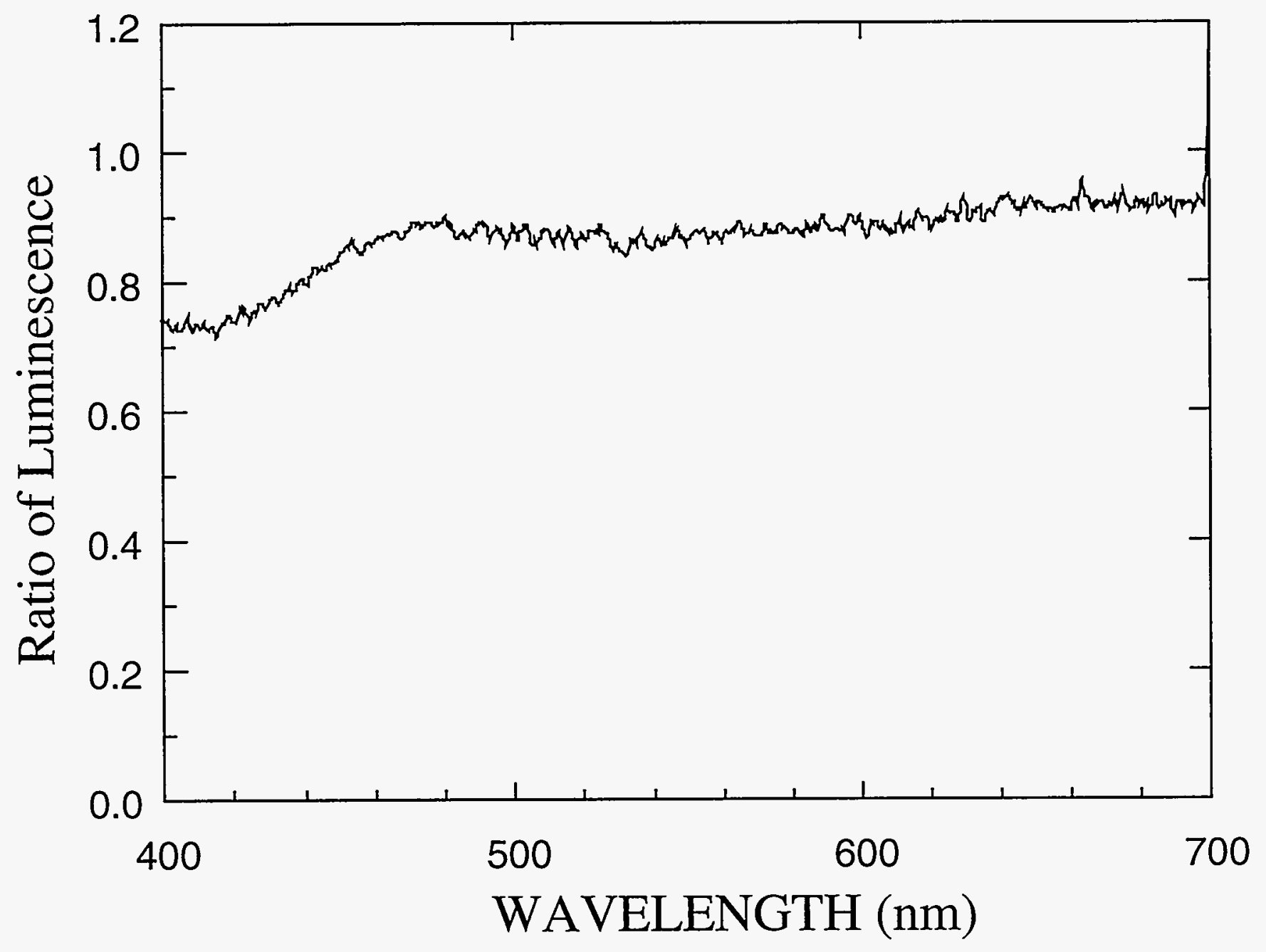

fig. 12 
Dr. F. Paoloni, Univ. of Wollongong, AUSTRALIA

Prof. R.C. Cross, Univ. of Sydney, AUSTRALIA

Plasma Research Lab., Australian Nat. Univ., AUSTRALIA

Prof. I.R. Jones, Flinders Univ, AUSTRALIA

Prof. F. Cap, Inst. for Theoretical Physics, AUSTRIA

Prof. M. Heindler, Institut für Theoretische Physik, AUSTRIA

Prof. M. Goossens, Astronomisch Instituut, BELGIUM

Ecole Royale Militaire, Lab. de Phy. Plasmas, BELGIUM

Commission-European, DG. XII-Fusion Prog., BELGIUM

Prof. R. Bouciqué, Rijksuniversiteit Gent, BELGIUM

Dr. P.H. Sakanaka, Instituto Fisica, BRAZIL

Prof. Dr. I.C. Nascimento, Instituto Fisica, Sao Paulo, BRAZIL Instituto Nacional De Pesquisas Espaciais-INPE, BRAZIL

Documents Office, Atomic Energy of Canada Ltd., CANADA

Ms. M. Morin, CCFMTokamak de Varennes, CANADA

Dr. M.P. Bachynski, MPB Technologies, Inc., CANADA

Dr. H.M. Skarsgard, Univ. of Saskatchewan, CANADA

Prof. J. Teichmann, Univ. of Montreal, CANADA

Prof. S.R. Sreenivasan, Univ. of Calgary, CANADA

Prof. T.W. Johnston, INRS-Energie, CANADA

Dr. R. Bolton, Centre canadien de fusion magnétique, CANADA

Dr. C.R. James, Univ. of Alberta, CANADA

Dr. P. Lukác, Komenského Universzita, CZECHO-SLOVAKIA

The Librarian, Culham Laboratory, ENGLAND

Library, R61, Rutherford Appleton Laboratory, ENGLAND

Mrs. S.A. Hutchinson, JET Library, ENGLAND

Dr. S.C. Sharma, Univ. of South Pacific, FIJI ISLANDS

P. Mähönen, Univ. of Helsinki, FINLAND

Prof. M.N. Bussac, Ecole Polytechnique,, FRANCE

C. Mouttet, Lab. de Physique des Milieux lonisés, FRANCE

J. Radet, CEN/CADARACHE - Bat 506, FRANCE

Prof. E. Economou, Univ. of Crete, GREECE

Ms. C. Rinni, Univ. of loannina, GREECE

Preprint Library, Hungarian Academy of Sci., HUNGARY

Dr. B. DasGupta, Saha Inst. of Nuclear Physics, INDIA

Dr. P. Kaw, Inst. for Plasma Research, INDIA

Dr. P. Rosenau, Israel Inst. of Technology, ISRAEL

Librarian, International Center for Theo Physics, ITALY

Miss C. De Palo, Associazione EURATOM-ENEA , ITALY

Dr. G. Grosso, Istituto di Fisica del Plasma, ITALY

Prof. G. Rostangni, Istituto Gas lonizzati Del Cnr, ITALY
Dr. H. Yamato, Toshiba Res \& Devel Center, JAPAN

Prof. I. Kawakami, Hiroshima Univ., JAPAN

Prof. K. Nishikawa, Hiroshima Univ., JAPAN

Librarian, Naka Fusion Research Establishment, JAERI, JAPAN

Director, Japan Atomic Energy Research Inst., JAPAN

Prof. S. Itoh, Kyushu Univ., JAPAN

Research Info. Ctr., National Instit. for Fusion Science, JAPAN

Prof. S. Tanaka, Kyoto Univ., JAFAN

Library, Kyoto Univ., JAPAN

Prof. N. Inoue, Univ. of Tokyo, JAPAN

Secretary, Plasma Section. Electrotechnical Lab., JAPAN

Dr. O. Mitarai, Kumamoto Inst. of Technology, JAPAN

Dr. G.S. Lee, Korea Basic Sci. Ctr., KOREA

J. Hyeon-Sook, Korea Atomic Energy Research Inst., KOREA

D.I. Choi, The Korea Adv. Inst. of Sci. \& Tech., KOREA

Prof. B.S. Liley. Univ. of Waikato. NEW ZEALAND

Inst of Physics, Chinese Acad Sci PEOPLE'S REP. OF CHINA Library, Inst. of Plasma Physics, PEOPLE'S REP. OF CHINA

Tsinghua Univ. Library, PEOPLE'S REPUBLIC OF CHINA

Z. Li, S.W. Inst Physics, PEOPLE'S REPUBLIC OF CHINA

Prof. J.A.C. Cabral, Instituto Superior Tecnico, PORTUGAL

Prof. M.A. Hellberg, Univ. of Natal, S. AFRICA

Prof. D.E. Kim, Pohang Inst. of Sci. \& Tech., SO. KOREA

Prof. C.I.E.M.A.T, Fusion Division Librany, SPAIN

Dr. L. Stenflo, Univ. of UMEA, SWEDEN

Library, Royal Inst. of Technology, SWEDEN

Prof. H. Wilhelmson, Chalmers Univ. of Tech., SWEDEN

Centre Phys. Des Plasmas, Ecole Polytech, SWITZERLAND

Bibliotheek, Inst. Voor Plasma-Fysica, THE NETHERLANDS

Asst. Prof. Dr. S. Cakir, Middle East Tech. Univ., TURKEY

Dr. V.A. Glukhikh,Sci. Res. Inst. Electrophys.I Apparatus, USSR

Dr. D.D. Ryutov, Siberian Branch of Academy of Sci., USSR

Dr. G.A. Eliseev, I.V. Kurchatov Inst., USSA

Librarian, The Ukr.SSR Academy of Sciences, USSR

Dr. L.M. Kovrizhnykh, Inst. of General Physics, USSR

Kemforschungsanlage GmbH, Zentralbibliothek, W. GERMANY

Bibliothek, Inst. Für Plasmaforschung. W. GERMANY

Prof. K. Schindler, Ruhr-Universitát Bochum, W. GERMANY

Dr. F. Wagner, (ASDEX), Max-Planck-Institut, W. GERMANY

Librarian, Max-Planck-Institut, W. GERMANY 